\title{
Erratum: Neurotransmitter signaling in the pathophysiology of microglia
}

\section{María Domercq, Nuria Vazquez-Villoldo and Carlos Matute*}

Department of Neuroscience, University of the Basque Country, Leioa, Spain

*Correspondence: carlos.matute@ehu.es

Edited by:

Amanda Sierra, University of the Basque Country EHU/UPV, Spain

\section{A commentary on}

Neurotransmitter signaling in the pathophysiology of microglia. by Domercq, M., Vázquez-Villoldo, N., and Matute, C. (2013). Front. Cell. Neurosci. 7:49. doi: 10.3389/fncel.2013.00049

At the top of page 5, the following changes need to be made.

... regulators of $\mathrm{P} 2 \mathrm{X} 4 \mathrm{R}$ expression in microglia have been described, such as the chemokine CCL2 (also known as monocyte chemoattractant protein,
MCP-1; Biber et al., 2011; Toyomitsu et al., 2012),....

Leaving the corrected text as follows:

... regulators of $\mathrm{P} 2 \mathrm{X} 4 \mathrm{R}$ expression in microglia have been described, such as the chemokine CCL21 (Biber et al., 2011)....

Page 16. The reference by Toyomitsu et al., 2012 should be removed.

\section{REFERENCES}

Biber, K., Tsuda, M., Tozaki-Saitoh, H., Tsukamoto, K., Toyomitsu, E., Masuda, T., et al. (2011). Neuronal CCL21 up-regulates microglia P2X4 expression and initiates neuropathic pain development. EMBO J. 30, 1864-1873. doi: 10.1038/emboj.2011.89

Received: 20 June 2013; accepted: 21 June 2013; published online: 09 July 2013.

Citation: Domercq M, Vazquez-Villoldo N and Matute C (2013) Erratum: Neurotransmitter signaling in the pathophysiology of microglia. Front. Cell. Neurosci. 7:107. doi: 10.3389/fncel.2013.00107

Copyright (c) 2013 Domercq, Vazquez-Villoldo and Matute. This is an open-access article distributed under the terms of the Creative Commons Attribution License, which permits use, distribution and reproduction in other forums, provided the original authors and source are credited and subject to any copyright notices concerning any third-party graphics etc. 